\title{
Pengembangan Sistem PengelolaAn Administrasi Menggunakan IndePendent Cloud Storage SeCara TERDISTRIBUSI
}

\author{
Nur Iksan ${ }^{\text {a,* }}$, Erika Devi Udayanti ${ }^{\text {b }}$, Djuniadi ${ }^{a}$ \\ ${ }^{a}$ Fakultas Teknik, Universitas Negeri Semarang \\ ${ }^{\mathrm{b}}$ Fakultas Ilmu Komputer, Universitas Dian Nuswantoro \\ ${ }^{\mathrm{a}, \mathrm{b}}$ Semarang, Indonesia \\ Email Address*: nur.iksan@mail.unnes.ac.id
}

\begin{abstract}
Berdasarkan hasil observasi pada SMK Negeri 5 Semarang, pengelolaan administrasi masih bersifat manual dan beberapa arsip digital disimpan dalam komputer yang tidak terkelola dengan baik serta sangat terbatas pada aksesnya. Beberapa aplikasi pengelolaan administrasi yang digunakan sudah dapat diakses melalui media internet, seperti Google Drive, Icloud, Dropbox dan SkyDrive. Bagaimanapun, layanan pada aplikasi tersebut masih menggunakan infrastruktur yang sangat bergantung pada provider sehingga pengguna memiliki beberapa keterbatasan seperti kendali akses penuh, kebijakan keamanan data, keberlanjutan layanan dan pemulihan data. Jika pengelolaan administrasi dilakukan pada sekolah maka perlu dipertimbangkan penggunaan sistem yang tidak bergantung pada suatu provider. Pengembangan sistem pengelolaan administrasi yang mandiri sangat diperlukan sehingga dokumen/arsip yang sangat penting dan bersifat rahasia dapat terjaga ketersediaan dan keamanannya. Untuk itu, diperlukan infrastruktur yang memadai dalam membangun independent cloud storage atau penyimpanan mandiri serta aplikasi pengelolanya. Pada proses bisnisnya, sistem ini dilakukan secara terdistribusi sehingga pengelolaan administrasi tidak lagi terpusat pada satu pengguna (staf tata usaha) melainkan semua entitas/pengguna (guru, kepala sekolah, staf tata usaha, bagian akademik, bagian kesiswaan, dan lain-lain). Untuk itu, kegiatan pengabdian masyarakat yang akan dilaksanakan meliputi pengembangan sistem pengelolaan administrasi menggunakan independent cloud storage secara terdistribusi. Dengan adanya kegiatan tersebut diharapkan dapat memberikan solusi pada permasalahan pengelolaan administrasi dan selanjutnya juga dapat meningkatkan kualitas pelayanan di SMK Negeri 5 Semarang
\end{abstract}

Keywords: Cloud Computing, Independent CLoud Storage, Papperless.

\section{INTRODUCTION}

Sampai saat ini media pembelajaran interaktif belum berkembang dengan optimal di Indonesia. Salah satu kendala pengembangan media pembelajaran interaktif adalah kurang dikuasainya teknologi pengembangan media interaktif oleh para pengajar, sehingga pengembangan materi pembelajaran interaktif dengan komputer kurang optimal. Sekarang ini, perkembangan teknologi khususnya Teknologi Informasi dan Komunikasi (TIK) begitu cepat seiring dengan berkembangnya ilmu pengetahuan. Namun perkembangan teknologi tidak semua berdampak positif, khususnya bagi anak-anak. Anak-anak cenderung lebih tertarik dalam aktifitas-aktifitas digital, seperti bermain game dan internet. Disisi lain aktifitas belajar anak cenderung menurun bahkan kalah dengan aktifitas digitalnya.

Kemajuan teknologi informasi yang pesat serta potensi pemanfaatannya secara luas, membuka peluang bagi pengaksesan, pengelolaan, dan pendayagunaan informasi secara cepat dan akurat. Pengembangan sistem manajemen organisasi jaringan bertujuan untuk meningkatkan kemampuan mengolah, mengelola, menyalurkan, dan mendistribusikan informasi dan pelayanan publik. Sekolah sebagai lembaga pendidikan formal memerlukan sebuah sistem manajeman yang dapat membantu mengelola sumber daya didalamnya, sebagai contoh pengelolaan akademik, kepegawaian, sarana dan prasarana, 
dan lain-lain. Disamping itu, terdapat pengelolaan sumber daya yang masih mempunyai banyak kelemahan dan perlu untuk segera diperbaiki, yaitu pengelolaan administrasi yang biasanya ditangani oleh bagian tata usaha. Pengelolaan administrasi mencakup kegiatan kearsipan yang berisi pelayanan data dan informasi yang dapat dilakukan dengan secara manual maupun secara elektronik.

Pengelolaan administrasi sekarang ini pada umumnya dilakukan secara elektronik yang dapat dibantu dengan adanya sistem salah satunya dalam kegiatan pengamanan dan penyimpanan arsip. Informasi yang yang disimpan pada dokumen dalam bentuk kertas rentan mengalami kehilangan atau terselip dan membutuhkan ruang untuk penyimpanan. Beberapa aplikasi pengelolaan administrasi menggunakan teknologi cloud computing yang dapat diakses melalui media internet, seperti Google Drive, Icloud, Dropbox dan SkyDrive [1]. Bagaimanapun, layanan pada aplikasi tersebut masih menggunakan infrastruktur yang sangat bergantung pada provider sehingga pengguna memiliki beberapa keterbatasan seperti kendali akses penuh, kebijakan keamanan data, keberlanjutan layanan dan pemulihan data.

Jika pengelolaan administrasi dilakukan pada sekolah maka perlu dipertimbangkan penggunaan sistem yang tidak bergantung pada suatu provider. Pengembangan sistem pengelolaan administrasi yang mandiri sangat diperlukan sehingga dokumen/arsip yang sangat penting dan bersifat rahasia dapat terjaga ketersediaan dan keamanannya. Untuk itu, diperlukan infrastruktur yang memadai dalam membangun independent cloud storage atau penyimpanan mandiri serta aplikasi pengelolanya. Pada proses bisnisnya, sistem ini dilakukan secara terdistribusi sehingga pengelolaan administrasi tidak lagi terpusat pada satu pengguna (staf tata usaha) melainkan semua entitas/pengguna (guru, kepala sekolah, staf tata usaha, bagian akademik, bagian kesiswaan, dan lain-lain). Kegiatan ini telah membangun sistem pengelolaan administrasi menggunakan independent cloud storage secara terdistribusi yang diharapkan dapat memberikan solusi pada permasalahan pengelolaan administrasi.

\section{INDEPENDENT Cloud STORAGE}

Permasalahan terkait pengelolaan administrasi merupakan suatu yang mendasar dan sangat perlu untuk dikembangkan sebuah sistem pengelolaan administrasi. Kondisi pengelolaan administrasi sekarang ini masih bersifat manual dan beberapa arsip digital disimpan dalam komputer yang tidak terkelola dengan baik serta sangat terbatas pada aksesnya. Gambar 1 menunjukkan perbandingan kondisi eksisting mitra dalam pengelolaan administrasi dan sistem pengelolaan yang akan dikembangkan.

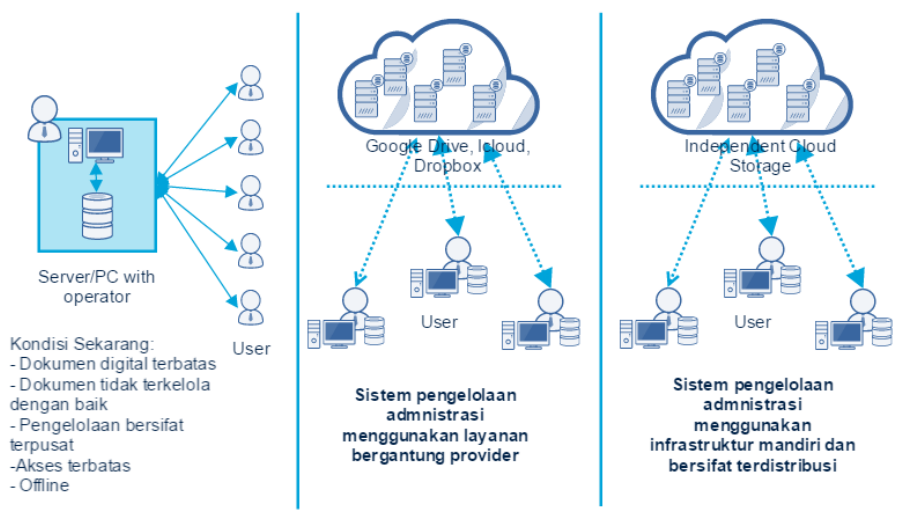

Gambar 1. Kondisi mitra dan sistem pengelolaan administrasi yang akan dikembangkan

Pengembangan sistem pengelolaan administrasi menggunakan independent cloud storage secara terdistribusi ini diharapkan dapat memberikan solusi pada permasalahan 
pengelolaan administrasi yang terjadi sekarang ini. Selanjutnya dengan adanya sistem ini juga diharapkan dapat meningkatkan kualitas pelayanan dalam kegiatan belajar mengajar di sekolah. Beberapa solusi yang ditawarkan adalah sebagai berikut:

1. Membangun infrastruktur server (web server, database server, dan lain-lain)

2. Instalasi ownCloud Enterprised Edition

3. Konfigurasi dan manajeman user

4. Melatih staf dan guru dalam menggunakan sistem pengelolaan administrasi

5. Melatih operator/staf IT (Information and Technology) dalam melakukan maintenance and repair.

Pengembangan infrastruktur dan penyediaan aplikasi pengelolaan administrasi menggunakan pendekatan/metode cloud computing seperti yang digunakan pada provider Google dan Apple. Teknologi cloud computing memungkinkan terintegrasinya layanan, infrastruktur dan platform (SaaS, IaaS, PaaS) [2] [3] [4]. Untuk menyediakan sistem berbasis cloud computing, pada kegiatan pengabdian ini dikembangkan infrastruktur yang didalamnya terdiri dari storage dan server. Pengembangan infrastrktur ini akan memungkinkan tersedianya media penyimpanan secara mandiri yang dikelola oleh server. Untuk menyediakan sistem pengelolaan, maka dikembangkan aplikasi pada server sehingga administrasi pada staf dan guru dapat dikelola dengan baik. Gambar 2 menunjukkan infrastruktur dan aplikasi pengelolaan administrasi berbasis cloud computing.
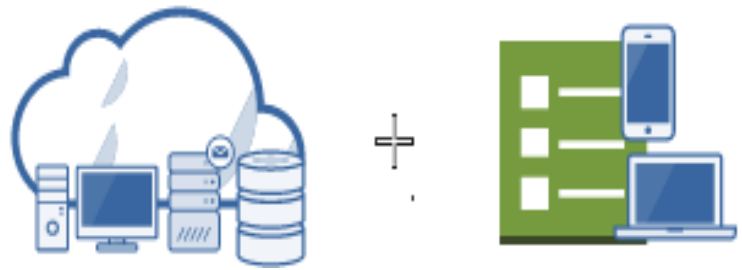

Gambar 2. Infrastruktur Independent Cloud Storage dan Aplikasi Pengelolaan Administrasi

Sistem pengelolaan administrasi memungkinkan staf dan guru dapat melakukan pengelolaan dokumen administrasi secara terdistribusi. Seperti yang ditunjukkan pada Gambar 3, user A dan user B yang merupakan staf/guru dapat melakukan penyimpanan dan sharing dokumen secara online. Aktifitas tersebut dikelola oleh sebuah server yang didalamnya terdapat aplikasi pengelolaan administrasi. Pada sistem ini juga dilengkapi sebuah storage yang memungkinkan penyimpanan dilakukan secara mandiri (independent storage) sehingga akses, ketersediaan dan keamanan dokumen yang bersifat rahasia dapat dijaga.

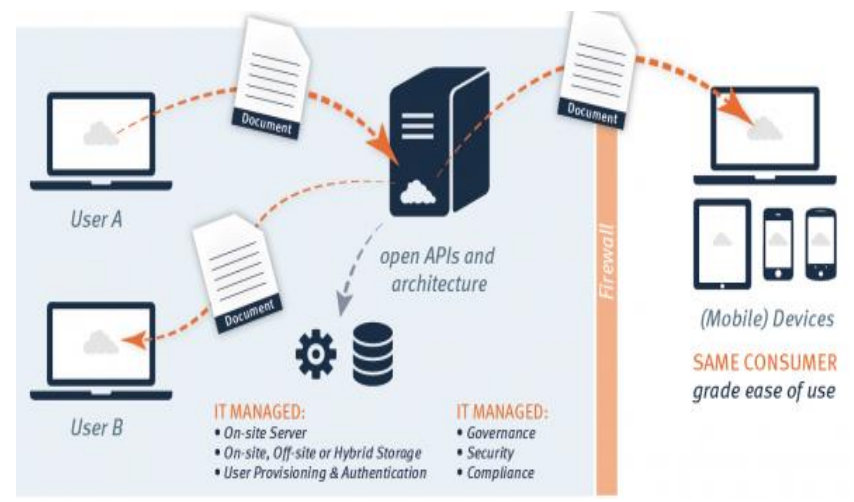

Gambar 3. Arsitektur Sistem Pengelolaan Administrasi 


\section{PelaksanaAn dan Hasil}

Membangun infrastruktur Independent Cloud Storage yaitu: instalasi ubuntu server, konfigurasi apache web server, instalasi php 5.5, instalasi mysql database, instalasi owncloud enterprise edition.

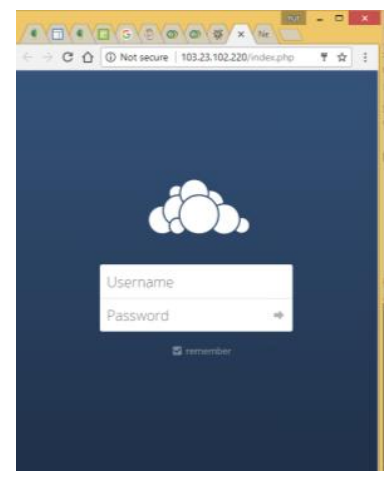

Gambar 3. Sistem Pengelolaan Administrasi

Konfigurasi dan pengaturan pada sistem pengelolaan administrasi, yaitu: Konfigurasi pada manajemen user: 1) membuat user baru, membuat group, pengaturan kuota penyimpanan, reset password user. 2) konfigurasi file sharing: transfer file ke user/group lain membuat public share membuat password pada public share konfigurasi database. Kegiatan yang dilaksanakan pada program pengabdian masyarakat dapat ditunjukkan pada Tabel 1 berikut.

Tabel 1. Rencana Kegiatan dan Langkah-Langkah Solusi

\begin{tabular}{|c|c|c|}
\hline & Parameter & Unit \\
\hline 1 & $\begin{array}{l}\text { Membangun infrastruktur Independent } \\
\text { Cloud Storage }\end{array}$ & $\begin{array}{ll}\text { Instalasi dan konfigurasi pada server: } \\
\text { 1. Instalasi Ubuntu server } \\
\text { 2. } \\
\text { 3. Instalasi PHP 5.5 } \\
\text { 4. Instalasi MySQL Database } \\
\text { 5. Instalasi OwnCLoud Enterprise Edition }\end{array}$ \\
\hline 2 & $\begin{array}{l}\text { Konfigurasi dan pengaturan pada } \\
\text { sistem pengelolaan administrasi }\end{array}$ & $\begin{array}{l}\text { Konfigurasi pada manajemen user: } \\
\text { 1. Membuat user baru } \\
\text { 2. Membuat group } \\
\text { 3. Pengaturan kuota penyimpanan } \\
\text { 4. Reset password user } \\
\text { Konfigurasi File Sharing: } \\
\text { 1. Transfer file ke user/group lain } \\
\text { 2. Membuat public share } \\
\text { 3. Membuat password pada public share }\end{array}$ \\
\hline 3 & $\begin{array}{lll}\text { Pengelolaan } & \text { administrasi } & \text { secara } \\
\text { terdistribusi } & & \end{array}$ & $\begin{array}{l}\text { 1. Pembuatan user untuk bagian tata usaha } \\
\text { 2. Pembuatan default directory pada bagian layanan } \\
\text { (akademik, kesiswaan, dan lain-lain) dan guru } \\
\text { untuk keperluan file sharing dengan tata usaha }\end{array}$ \\
\hline 4 & $\begin{array}{l}\text { File sharing oleh bagian layanan } \\
\text { (akademik, kesiswaan) dan guru serta } \\
\text { tata usaha }\end{array}$ & $\begin{array}{lll}\text { 1. Pangunggahan file pada direktori yang sudah } \\
\text { ditentukan }\end{array}$ \\
\hline
\end{tabular}




\section{KESIMPULAN}

Berdasarkan hasil kegiatan pengabdian yang dilakukan, maka dapat disimpulkan sebagai berikut:

1. Dokumen yang masih masih manual tersimpan secara digital dalam server sehingga lebih efisien dalam pengelolaan dan mengurangi terjadinya dokumen selip dan bahkan hilang

2. Pengelolaan dokumen administrasi dapat dilakukan secara distribusi baik oleh operator/bagian tata usaha.

3. Pengelolaan administrasi yang digunakan berbasis cloud computing dan dikelola secara mandiri sehingga tidak terbatas pada akses, ketersediaan dan keamanan.

4. Sistem administrasi independent Cloud Storage dapat meningkatkan kualitas pelayanan administrasi sehingga mempercepat dalam proses pelayanan sekolah

\section{REFERENCES}

[1] I. Drago, "Benchmarking personal cloud storage," in conference on Internet measurement, Barcelona, 2013.

[2] H. Tianfield, "Cloud computing architectures," in IEEE International Conference on Systems, Man, and Cybernetics (SMC), 2011.

[3] W.-T. Tsai, X. Sun and J. Balasooriya, "Service-Oriented Cloud Computing Architecture," in International Conference on Information Technology: New Generations (ITNG), 2010.

[4] H. Zhang and X. Yang, "Cloud Computing Architecture Based-On SOA," in International Symposium on Computational Intelligence and Design (ISCID), 2012.

[5] LP2M, "Data Penelitian dan Pengabdian Kepada Masyarakat 2016," UNNES, Semarang, 2016.

[6] S. Jun and Y. Sha-sha, "The application of cloud storage technology in SMEs," in International Conference on E-Business and E-Government (ICEE), 2011. 